\title{
Pengaruh Metode Simulasi Terhadap Keterampilan Pelaksanaan Kegiatan 3M ( Mencuci Tangan, Memakai Masker, Menjaga Jarak ) Pada Siswa Sekolah Menengah Pertama
}

\author{
Ridawati Sulaeman, Politeknik Kesehatan Kemenkes Mataram, \\ ridasulaeman@gmail.com \\ Risma Dwi Lestari, Politeknik Kesehatan Kemenkes Mataram, \\ rsmdwlestari@gmail.com \\ Awan Dramawan, Politeknik Kesehatan Kemenkes Mataram \\ awandramawan64@gmail.com \\ Dewi Purnamawati, Politeknik Kesehatan Kemenkes Mataram, \\ dewiwahid99@gmail.com
}

Received: 22 August 2021; Revised: 02 October 2021; Accepted: 28 December 2021 DOI: http://dx.doi.org/10.37905/aksara.8.1.733-740.2022

\begin{abstract}
ABSTRAK
Prevalensi Covid-19 di Indonesia cukup tinggi. Rendahnya kesadaran untuk menjalankan perilaku hidup bersih dan sehat (PHBS) pada anak sekolah menyebabkan siswa lebih mudah terkena penyakit. Usaha Kesehatan Sekolah (UKS) sebagai wahana untuk menciptakan derajat kesehatan sedini mungkin dan salah satu programnya adalah pendidikan kesehatan yang berkaitan dengan perilaku hidup bersih dan sehat (PHBS). Program 3M (mencuci tangan, menggunakan masker, dan menjaga jarak) adalah serangkaian upaya pencegahan penyebaran dan penularan Covid-19.. Tujuan penelitian untuk mengetahui pengaruh metode simulasi terhadap keterampilan pelaksanaan kegiatan $3 \mathrm{M}$ (mencuci tangan, menggunakan masker, dan menjaga jarak) pada siswa SMPN 3 Narmada. pre experimental dengan rancangan one grup pretest - posttest. Populasi siswa yang mengikuti kelompok belajar di Dusun Sedau Gondang sebanyak 37 siswa. Tekhnik sampling total sampling. Jumlah sampel 37 siswa. Analis menggunkan uji Wilcoxon.

Hasil : keterampilan 3M sebelum dilakukan metode simulasi cukup sebanyak $62.2 \%$ dan kurang $35.1 \%$, setelah dilakukan sebagian besar kategori baik sebanyak $64.9 \%$. Hasil uji statistik $p$-value $0,000(p<0,05)$. menunjukkan adanya pengaruh metode simulasi terhadap keterampilan 3M siswa SMPN 3 Narmada.

Simpulan : metode simulasi dapat meningkatkan keterampilan, disarankan kepada kegiatan Usaha Kesehatan Sekolah (UKS) pada siswa SMPN 3 Narmada, perlu melaksanakan metode ini kepada seluruh siswa sehingga dapat menerapkan 3M dalam kehidupan sehari-hari.
\end{abstract}

Kata Kunci : Metode Simulasi, Keterampilan pelaksanaan 3 M (mencuci tangan, menggunakan masker, dan menjaga jarak) 


\begin{abstract}
The prevalence of Covid-19 in Indonesia is quite high. The low awareness to carry out clean and healthy living behavior (PHBS) in school children causes students to be more susceptible to disease. School Health Business (UKS) is a vehicle for creating health degrees as early as possible and one of the programs is health education related to clean and healthy living behavior (PHBS). The $3 \mathrm{M}$ program (washing hands, using masks, and maintaining distance) is a series of efforts to prevent the spread and transmission of Covid-19. SMPN 3 Narmada.

Pre-experimental design with one group pretest - posttest design. The population of students who take part in study groups in Sedau Gondang Hamlet is 37 students. Total sampling technique sampling. The number of samples is 37 students. Analysts use the Wilcoxon test.

Results: 3M skills before the simulation method is sufficient as much as $62.2 \%$ and less than $35.1 \%$, after most of the good categories are $64.9 \%$. The results of the statistical test $\mathrm{p}$-value $0.000(\mathrm{p}<0.05)$. shows the effect of the simulation method on the $3 \mathrm{M}$ skills of SMPN 3 Narmada students.

Conclusion: the simulation method can improve skills, it is recommended for School Health Business (UKS) activities for SMPN 3 Narmada students, it is necessary to implement this method for all students so that they can apply $3 \mathrm{M}$ in everyday life.
\end{abstract}

Keywords: Simulation Method, 3 M implementation skills (washing hands, using masks, and keeping a distance)

\title{
LATAR BELAKANG
}

Kesehatan adalah salah satu unsur penting bahkan sangat strategis dalam upaya pembangunan manusia Indonesia di samping pendidikan dan ekonomi karena dengan kesehatan, seseorang akan mempunyai kesempatan dan kemampuan yang lebih besar untuk memenuhi kebutuhan pendidikan serta ekonominya sebagai langkah peningkatan kualitas sumberdaya (Banun, 2016). Seiring perkembangan zaman resiko penularan penyakit makin massif terjadi, maraknya penyakit yang disebabkan oleh infeksi virus maupun bakteri membuat panik sebagian besar orang. Salah satu contoh kasus mematikan, yaitu penyakit Covid-19 yang disebabkan oleh virus yang disebabkan oleh virus SARS-CoV-2 atau sering disebut virus corona. Prevalensi Covid-19 di Indonesia cukup tinggi (Sukesih et al., 2020). Rendahnya kesadaran untuk menjalankan perilaku hidup bersih dan sehat (PHBS) pada anak sekolah menyebabkan siswa lebih mudah terkena penyakit.

Berdasarkan data WHO 2020, jumlah kematian akibat virus corona semakin meningkat dari-hari ke hari. Data per tanggal 20 januari 2021 jumlah kematian di dunia akibat virus corona mencapai 2.085.467 (2.14\%). Di Indonesia, jumlah ke kematian akibat virus corona mencapai $27.203(2,86 \%)$ dari total sebanyak 951.651 kasus. Di NTB pada tahun 2019, kasus COVID-19 mencapai 6.792 kasus yang menyebabkan 319 orang meninggal dunia. Lombok Barat menempati urutan ke 2 terbanyak kasus corona di NTB dengan jumlah kasus sebanyak 818 kejadian yang menyebabkan 102 orang meninggal dunia. Berdasarkan data yang diperoleh dari profil Dinas Kesehatan Lombok Barat di daerah Narmada terdapat 70 orang terkonfirmasi Covid-19 yang menyebabkan 3 oran meninggal dunia dan terdapat 291 kasus suspect Covid-19. Di Dusun Sedau Gondang terdapat 1 kasus kematian akibat Covid-19 dan 4 kasus positif Covid-19 yang salah

734 AKSARA: Jurnal Ilmu Pendidikan Nonformal 
satunya merupakan siswa SMPN 3 Narmada. Berdasarkan Riskesdas 2018, didapatkan beberapa data mengenai perilaku penduduk Indonesia tentang perilaku hidup bersih dan sehat (PHBS) penduduk secara umum, hanya $47 \%$ penduduk Indonesia yang telah dapat melakukan cuci tangan menggunakan sabun dengan benar. Di NTB penduduk yang telah memenuhi kriteria PHBS yang baik sebesar 15,8\%. Hanya terdapat dua kabupaten/kota yang penduduknya telah memenuhi kriteria PHBS baik, yaitu Kab. Bima dan Kota Mataram (Riskesdas NTB, 2018). Berdasarkan hasil wawancara dan observasi, 7 dari 10 siswa belum memahami dan belum dapat melakukan PHBS yang baik dan benar yang berkaitan dengan 3M (mencuci tangan, menggunakan masker, dan menjaga jarak).

Upaya pemeliharaan dan peningkatan kesehatan harus dimulai sedini mungkin yaitu sejak usia kanak-kanak bahkan sejak dalam kandungan. Pembinaan dan pembangunan kesehatan siswa melalui Usaha Kesehatan Sekolah (UKS) merupakan salah satu rantai dalam meningkatkan derajat kesehatan penduduk karena Usaha Kesehatan Sekolah (UKS) juga sebagai wahana untuk menciptakan derajat kesehatan sedini mungkin (Yetty, 2008). Salah satu program UKS adalah pendidikan kesehatan yang berkaitan dengan perilaku hidup bersih dan sehat (PHBS). Program 3M (mencuci tangan, menggunakan masker, dan menjaga jarak) adalah serangkaian upaya pencegahan penyebaran dan penularan Covid-19. Penggunaan masker merupakan bagian dari rangkaian komprehensif langkah pencegahan dan pengendalian yang dapat membatasi penyebaran penyakit-penyakit virus saluran pernafasan tertentu, termasuk Covid-19. Masker dapat digunakan baik untuk melindungi orang yang sehat (dipakai untuk melindungi diri sendiri saat berkontak dengan orang yang terinfeksi) atau untuk mengendalikan sumber (dipakai oleh orang yang terinfeksi untuk mencegah penularan lebih lanjut). Terlepas dari penggunaan masker, kebersihan tangan dan penjagaan jarak fisik sangat penting untuk mencegah penularan Covid 19 dari orang ke orang (WHO, 2020).

Proses belajar mengajar dapat berhasil jika didukung dan dipengaruhi oleh media pembelajaran dan metode yang digunakan. Metode belajar dapat memberikan pengaruh positif yang signifikan terhadap proses belajar, yang berarti jika motivasi belajar meningkat, maka cenderung meningkatkan kompetensinya (Sinta Silvana, 2017). Skill atau keterampilan merupakan suatu kemampuan untuk menuangkan pengetahuan ke dalam praktik sehingga tercapai hasil yang diinginkan, (Suprapto, 2009). Metode pembelajaran yang akan digunakan dalam penelitian ini adalah penerapan metode simulasi. Metode pembelajaran simulasi dapat menggambarkan keadaan sebenarnya dari suatu keadaan, penyederhanaan dari suatu fenomena di dunia nyata. Simulasi adalah suatu tiruan dan perbuatan pura-pura saja. Metode pembelajaran ini dipilih karena metode pembelajaran ini lebih menekankan pada keaktifan peserta didik dalam membangun konsep/pengetahuan yang dimiliki untuk mengatasi permasalahan yang dihadapi (Wahyuni \& Baroroh, 2015).

Berdasarkan latar masalah dan fenomena yang terjadi di atas, maka peneliti tertarik untuk melakukan penelitian tentang "Pengaruh metode simulasi terhadap keterampilan pelaksanaan kegiatan 3M (mencuci tangan, menggunakan masker, dan menjaga jarak) pada siswa SMPN 3 Narmada Tahun 2021”.

\section{METODE}

Penelitian ini menggunakan rancangan penelitian Pre-Experimental dengan pendekatan One Group Pre-post test Design. Populasi dalam penelitian ini adalah siswa- 
siswi SMPN 3 Narmada di Dusun Sedau Gondang yang mengikuti kelompok belajar dengan usia 13-15 tahun berjumlah 37 orang. Tekhnik pengambilan sampel menggunakan total sampling. Jumlah sampel sebanyak 37 sampel. Penelitian ini dilakukan dengan cara memberikan pretest (observasi awal) dengan cara siswa melakukan tindakan 3M (mencuci tangan, menggunakan masker, dan menjaga jarak) dengan bantuan cheklist. Kemudian dilanjutkan peneliti melakukan simulasi pergroup (kelompok belajar) dan melatih siswa untuk menerapkan kegiatan 3M. Simulasi dilaksanakan selama 1 minggu dalam 3 kali pertemuan. Setiap sesi dalam pertemuan berlangsung selama 2-3 jam Selanjutnya pelaksanaan post test (observasi akhir). Untuk melihat pengaruh metode simulasi terhadap keterampilan pelaksanaan kegiatan $3 \mathrm{M}$ digunakan uji willcoxon.

\section{HASIL DAN PEMBAHASAN}

\section{A. HASIL}

Penelitian ini dilaksanakan pada SMP Negeri 3 Narmada kabupaten Lombok Barat yang mengikuti kelompok belajar siswa yang berada di di Dusun Sedau Gondang. Karakteristik responden dapat dilihat pada tabel 1 :

Tabel 1 : Karakteristik Responden di Kelompok Belajar Siswa SMPN 3 Narmada Pada Bulan Maret 2021

\begin{tabular}{|c|c|c|}
\hline Variabel & \multicolumn{2}{|c|}{ Jumlah } \\
\hline Usia (Tahun) & 9 & 24,4 \\
\hline 13 & 14 & 37,8 \\
\hline 14 & 14 & 37,8 \\
\hline 15 & $\mathbf{3 7}$ & $\mathbf{1 0 0}$ \\
\hline Jumlah & 10 & 27 \\
\hline Jenis Kelamin & 27 & 73 \\
\hline Laki-laki & $\mathbf{3 7}$ & $\mathbf{1 0 0}$ \\
\hline Jumpuan & &
\end{tabular}

Tabel 1 memperlihatkan bahwa responden terbanyak berusia 14 tahun dan 15 tahun masing-masing $37.8 \%$ sedangkan jenis kelamin perempuan sebanayk $73 \%$

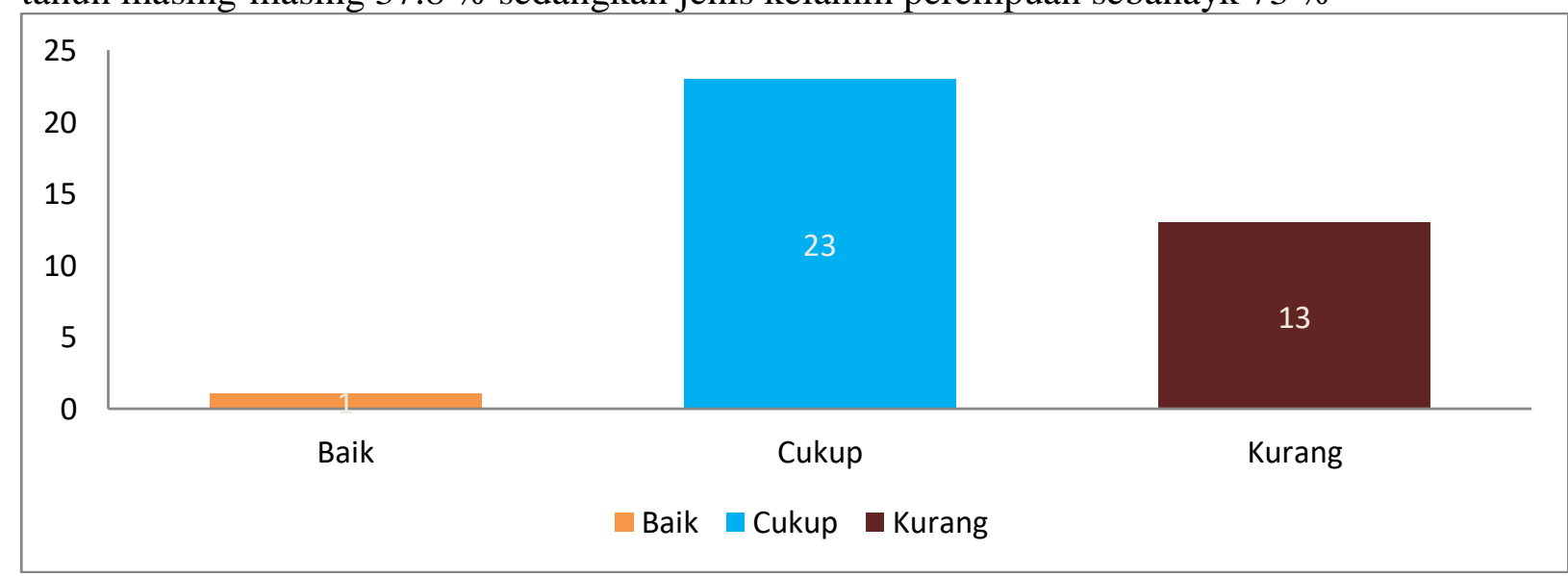

Gambar 1. Distribusi Keterampilan Siswa Sebelum Dilakukan Metode Simulasi tentang 3M (Mencuci Tangan, Menggunakan Masker dan Menjaga Jarak) di Kelompok Belajar Siswa SMPN 3 Narmada Pada Bulan Maret 2021 
Berdasarkan gambar 1 menunjukkan bahwa sebagian besar keterampilan siswa tentang 3M (Mencuci tangan, Menggunakan masker dan Menjaga jarak) termasuk kategori cukup sebanyak 23 orang $(62,2 \%)$.

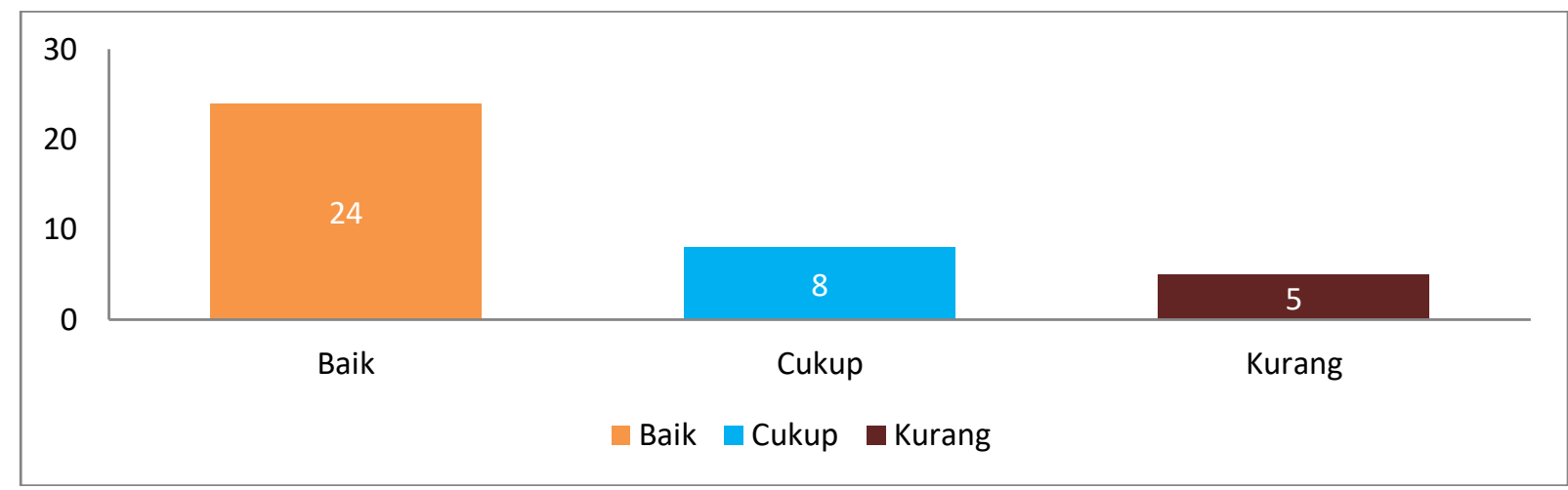

Gambar 2. Distribusi Keterampilan Siswa Setelah Dilakukan Metode Simulasi tentang 3M (Mencuci Tangan, Menggunakan Masker dan Menjaga Jarak) di Kelompok Belajar Siswa SMPN 3 Narmada Pada Bulan Maret 2021

Gambar 2 menunjukkan bahwa sebagian besar keterampilan siswa tentang 3M (Mencuci tangan, Menggunakan masker dan Menjaga jarak) termasuk kategori baik sebanyak 24 orang siswa $(64,9 \%)$.

Tabel 2. Analisis Pengaruh Metode Simulasi Terhadap Keterampilan Siswa tentang 3M (Mencuci tangan, Menggunakan masker dan Menjaga jarak) di Kelompok Belajar Siswa SMPN 3 Narmada Pada Bulan Maret 2021

\begin{tabular}{|c|c|c|c|c|c|c|}
\hline \multirow{2}{*}{ No. } & \multirow{2}{*}{ Keterampilan } & \multicolumn{2}{|c|}{ Pre } & \multicolumn{2}{c|}{ Post } & \multirow{2}{*}{$\boldsymbol{\rho}$} \\
\cline { 3 - 6 } & & $\mathbf{N}$ & $\mathbf{\%}$ & $\mathbf{N}$ & $\mathbf{\%}$ & \multirow{2}{*}{$\mathbf{0 , 0 0}$} \\
\hline 1 & Baik & 1 & 2,7 & 24 & 64,9 & \\
\hline 2 & Cukup & 23 & 62,2 & 8 & 21,6 & \\
\hline 3 & Kurang & 13 & 35,1 & 5 & 13,5 & \\
\hline & Total & $\mathbf{3 7}$ & $\mathbf{1 0 0}$ & $\mathbf{3 7}$ & $\mathbf{1 0 0}$ & \\
\hline
\end{tabular}

Hasil statistik menggunakan uji nonparametric yaitu uji willcoxon untuk pendidikan kesehatan menggunakan metode simulasi terhadap keterampilan siswa tentang $3 \mathrm{M}$ (Mencuci tangan, Menggunakan masker dan Menjaga jarak) diperoleh $\rho$ adalah 0.00 atau nilai $\rho(0,00)<\alpha(0,05)$ artinya metode simulasi berpengaruh terhadap peningkatan keterampilan siswa tentang 3M (Mencuci tangan, Menggunakan masker dan Menjaga jarak).

\section{B. PEMBAHASAN}

1. Keterampilan Pelaksanaan Kegiatan 3M ( Mencuci Tangan, Memakai Masker, Menjaga Jarak) Pada Siswa Sebelum dilakukan Metode Simulasi di Kelompok Belajar Siswa SMPN 3 Narmada.

Tingkat keterampilan siswa sebelum di berikan Pendidikan Kesehatan tentang 3M dikategorikan cukup dan kurang. Hal tersebut ditunjukkan melalui pre test menunjukkan sebanyak 23 orang $(62,2 \%)$ kategori cukup dan kategori kurang mampu sebanyak 13 orang $(35.1 \%)$. Hal ini dikarenakan siswa tidak memiliki pengalaman dan pengetahuan tentang kegiatan Usaha Kesehatan Sekolah (UKS) khususnya tentang 3M (Mencuci tangan, Memakai masker dan Menjaga jarak) dan tidak pernah 
mengikuti pelatihan semacamnya. Responden cenderung tidak memiliki pengetahuan tentang pemahaman tentang kegiatan Usaha Kesehatan Sekolah (UKS) khususnya tentang 3M (Mencuci tangan, Memakai masker dan Menjaga jarak) dan apabila tidak diberikan pelatihan tentang $3 \mathrm{M}$ dengan metode simulasi dapat mengakibatkan perilaku atau keterampilan siswa termasuk dalam kategori kurang.

Beberapa faktor yang mempengaruhi keterampilan seseorang dalam melakukan sebuah tindakan adalah pengetahuan mencakup segenap apa yang diketahui tentang obyek tertentu dan disimpan di dalam ingatan. Pengetahuan dipengaruhi oleh berbagai faktor yaitu latar belakang pendidikan, pengalaman, usia dan jenis kelamin. Pengalaman akan memperkuat kemampuan dalam melakukan sebuah tindakan (keterampilan) merupakan sebuah keinginan yang membangkitkan motivasi dalam diri seorang perawat dalam rangka mewujudkan tindakan-tindakan tersebut. (Hasanah, 2015)

2. Keterampilan Pelaksanaan Kegiatan 3M ( Mencuci Tangan, Memakai Masker, Menjaga Jarak) Pada Siswa Setelah dilakukan Metode Simulasi di Kelompok Belajar Siswa SMPN 3 Narmada.

Berdasarkan hasil penelitian, keterampilan siswa setelah dilakukan Pendidikan Kesehatan menggunakan metode simulasi tentang 3M (Mencuci tangan, Menggunakan masker dan Menjaga jarak) sebagian besar termasuk dalam kategori baik yaitu sebanyak 24 orang $(64,9 \%)$.

Metode simulasi merupakan metode pembelajaran yang mengutamakan peranan siswa secara langsung (belajar melalui pengalaman) sedangkan aktivitas siswa serta pemahaman siswa dipengaruhi oleh bagaimana siswa belajar melalui pengalaman dan gaya belajar yang dimiliki siswa tersebut untuk menerima dan mengolah informasi dalam pembelajaran yang dilakukan. Metode simulasi juga merupakan kegiatan pembelajaran yang melibatkan aktivitas fisik. Melalui metode ini pula, keaktifan, ketertarikan, kesenangan dalam diri siswa ketika mengikuti proses pembelajaran dapat meningkat. (Herlina, 2019)

Manfaat dari pemberian metode simulasi ini dapat dibuktikan dengan peningkatan hasil dari data pre-test dan post test yang ditandai dengan perubahan perilaku yang dinilai dalam lembar kuisioner secara individu. Pemberian Pendidikan Kesehatan dengan metode simulasi memberikan dampak positif, dimana responden yang mengikuti kegiatan dengan antusias dan aktif terbukti memperoleh manfaat dari hasil yang signifikan dari kegiatan ini. Hal ini terbukti bahwa metode simulasi sangat efektif dan interaktif untuk meningkatkan keterampilan 3M (Mencuci tangan, Menggunakan masker dan Menjaga jarak).

3. Pengaruh Metode Simulasi Terhadap Keterampilan Pelaksanaan Kegiatan 3M ( Mencuci Tangan, Memakai Masker, Menjaga Jarak) Pada Siswa Setelah dilakukan Metode Simulasi di Kelompok Belajar Siswa SMPN 3 Narmada.

Hasil uji statistik dengan menggunakan uji Wilcoxon didapatkan Sig. (2-tailed) sebesar $0,000(\rho<0,05)$. Hasil tersebut menunjukkan bahwa Ha diterima dan $\mathrm{H}_{0}$ ditolak yang artinya ada pengaruh metode simulasi terhadap keterampilan pelaksanaan kegiatan Usaha Kesehatan Sekolah (UKS) pada siswa SMPN 3 Narmada.

Pada hakikatnya anak senang bermain karena dengan bermain pertumbuhan dan perkembangan daya tubuh anak dapat berkembang dengan baik. Di masa usia ini diperlukan stimulus yang baik karena di usia 6-12 tahun semua yang diajarkan akan menempel secara permanen, otak anak pada usia ini bekerja $80 \%$ yang ditandai dengan

AKSARA: Jurnal Ilmu Pendidikan Nonformal 
cepat pada perubahan fisik, kognitif, emosional, sosial dan sebagainya (Rahman \& Kristiyanto, 2017). Menurut Notoadmodjo (2010), pendidikan kesehatan adalah segala upaya yang direncanakan untuk mempengaruhi orang lain sehingga mau melakukan pelaku kesehatan tertentu.

Metode simulasi adalah rancangan pembelajaran yang bersifat praktis guna mengembangkan skill baik keterampilan mental ataupun keterampilan fisik/teknis. Metode pembelajaran ini dapat membawa siswa pada situasi yang seakan-akan benar karena adanya kesulitan dan ketidak mungkinan untuk melakukan hal yang sebenarnya. Metode ini membentuk siswa dengan cara melakukan prtaktek atau suatu proses keadaan yang sebenarnya atau state of affrais, membantu bersosialisasi dengan keadaan nyata, mengasah keterampilan, kepekaan dan berfikir untuk mengambil suatu keputusan (Shoimin, 2014).

Pengalaman belajar menggunakan metode simulasi akan menimbulkan responsrespons tertentu dari pihak siswa. Pengalaman yang berupa pelajaran akan menghasilkan perubahan (pematangan, pendewasaan) pola tingkah laku, perubahan di dalam sistem nilai, di dalam perbendaharaan konsep konsep (pengertian) serta didalam kekayaan informasi. (Daryanto, 2013)

Penggunaan metode simulasi dapat meningkatkan kemampuan peserta melakukan interaksi sosial dan membina hubungan komunikatif dalam kelompoknya. Aktivitas siswa yang cukup tinggi dalam proses pembelajaran membangkitkan perasaan keterlibatan langsung dalam pembelajaran, membangkitkan imajinasi, meningkatkan berfikir secara kritis karena proses pembelajaran menuntut peserta didik untuk selalu aktif. Dengan menggunakan metode simulasi siswa belajar memahami kegiatan dan memberi kesempatan berlatih mengambil keputusan yang mungkin tidak dapat dilakukan dalam situasi nyata, selain itu juga dapat membentuk kemampuan siswa menilai situasi dan membuat pertimbangan berdasarkan kemungkinan yang muncul, meningkatkan disiplin dan meningkatkan. (Anitah \& Sri, 2014)

Perubahan peningkatan keterampilan sebagian besar responden (siswa) dapat mengerjakan langkah-langkah melakukan kegiatan 3M (Mencuci tangan, Memakai masker, dan Menjaga jarak) secara berurutan sesuai dengan checklist yang telah ditentukan. Peningkatan keterampilan pada penelitian ini disebabkan juga karena pemberian materi yang bersifat focus dan dilakukannya simulasi secara langsung pada siswa, sehingga siswa dapat melihat dan mempraktikkan bagaimana cara melakukan 3M (Mencuci tangan, Memakai masker, dan Menjaga jarak) tersebut. Peningkatan keterampilan merupakan salah satu tolok ukur yang didalamnya terdapat kegiatan belajar mengajar dari segi kognitif melalui pemberian informasi pada responden. Perubahan perilaku responden didasari oleh pengetahuan akan lebih lama dibandingkan dengan tanpa didasari oleh pengetahuan.

Hasil penelitian menunjukkan bahwa metode simulasi yang dilakukan memberikan pengaruh terhadap keterampilan kegiatan pelaksanaan 3M pada siswa. Pada mulanya, sebelum diberikan pendidikan kesehatan melalui metode simulasi sebagian besar responden memiliki keterampilan dalam kategori cukup dan kurang. Namun setelah dilakukan pendidikan kesehatan melalui metode simulasi sebagian besar responden memiliki keterampilan dalam kategori baik dengan responden mampu mempraktikkan secara berurutan dan benar terkait dengan 3M (Mencuci tangan, Memakai masker, dan Menjaga jarak). 


\section{KESIMPULAN}

Pemberian Pendidikan Kesehatan menggunakan Metode simulasi memberikan pengaruh positif terhadap siswa melakukan 3M, sehingga disarankan kepada kegiatan Usaha Kesehatan Sekolah (UKS) SMPN 3 Narmada, perlu melaksanakan metode ini kepada seluruh siswa sehingga dapat menerapkan $3 \mathrm{M}$ dalam kehidupan sehari-hari. Penerapan 3M ini dapat memberikan salah satu solusi untuk pencegahan dan penangangan penyebaran covid-19.

\section{REFERENSI}

Anitah W \& Sri. 2014. Strategi Pembelajaran. Banten : Universitas Terbuka Banten

Banun, T. S. (2016). Hubungan antara Pengetahuan PHBS dengan Pola Hidup Sehat Siswa di SD Tamanan. Jurnal Pendidikan Guru Sekolah Dasar.

Daryanto. (2013). INOVASI PEMBELAJARAN EFEKTIF. Yrama Widya.

Dinas Kesehatan Provinsi NTB. (2020). Data Covid-19. corona.ntbprop.go.id

Hasanah, U. N. (2015). Hubungan Tingkat Pengetahuan Dengan Ketrampilan Perawat Dalam Melakukan Tindakan Bantuan Hidup Dasar (BHD) di RSUD Kabupaten Karanganyar. Program Studi S1 Keperawatan STIKes Kusuma Husada Surakarta. http://digilib.stikeskusumahusada.ac.id

Herlina, S. (2019). Pengaruh Simulasi Pelatihan Bantuan Hidup Dasar (Bhd) Terhadap Motivasi Dan Skill Resusitasi Jantung Paru (Rjp) Pada Karang Taruna Rw 06 Kampung Utan Kelurahan Krukut Depok. Jurnal Keperawatan Widya Gantari Indonesia, 3(2), 7. https://doi.org/10.52020/jkwgi.v3i2.1038

Notoatmodjo, S. (2010). Ilmu perilaku kesehatan. PT Rineka Cipta.

Rahman, A., \& Kristiyanto, A. (2017). The different effect of playing and training learning approach on the ability of the straddle style high jump of the 5th grade male students of Djama ' atul Ichwan elementary school Surakarta academic year 2013 / 2014. International Journal of Physiology, Nutrition and Physical Education, 2(2), 80-83.

Riskesdas. (2018). Hasil Utama Riskesdas 2018.

Shoimin, A. (2014). 68 Model Pembelajaran Inovatif dalam Kurikulum 2013. Ar-Ruzz Media.

Sinta Silvana, T. (2017). Hubungan antara Motivasi Belajar dan Pembelajaran Berbasis Web pada Mata Pelajaran Simulasi dan Komunikasi Digital di SMK Negeri 2 Surabaya. It-Edu, 2(02), 57-66.

Sukesih, S., Usman, U., Budi, S., \& Sari, D. N. A. (2020). Pengetahuan Dan Sikap Mahasiswa Kesehatan Tentang Pencegahan Covid-19 Di Indonesia. Jurnal Ilmu Keperawatan Dan Kebidanan, 11(2), 258. https://doi.org/10.26751/jikk.v11i2.835

Suprapto, T. (2009). Pengantar Teori dan Manajemen Komunikasi. MedPress.

Wahyuni, D., \& Baroroh, K. (2015). Penerapan Metode Pembelajaran Simulasi Untuk Meningkatkan Aktivitas Dan Prestasi Belajar Ekonomika Mikro. Jurnal Ekonomi Dan Pendidikan, 9(1). https://doi.org/10.21831/jep.v9i1.4155

WHO. (2020). Coronavirus disease (COVID-19) pandemic. https://www.who.int/emergencies/diseases/novel-coronavirus-2019

Yetty, A. (2008). Pelaksanaan usaha kesehatan sekolah di sekolah dasar gugus VI Kecamatan Lima Kaum Batusangkar. Universitas Negeri Padang. 